\title{
Nano concrete aggregation with steel fibers: A problem to enhance the tensile strength of concrete
}

\author{
Van Thuc Ngo ${ }^{1}$, Thanh Quang Khai Lam ${ }^{1, *}$ Thi My Dung Do ${ }^{1}$, and Trong Chuc Nguyen ${ }^{2}$ \\ ${ }^{1}$ Mien Tay Construction University, Vinh Long, Vietnam \\ ${ }^{2}$ Le Quy Don Technical University, Hanoi, Vietnam
}

\begin{abstract}
In Vietnam, nano technology began to be interested in research and development, typically the seminar program of production research, silicon nano applications from waste materials and investment projects to build silicon nano manufacturing in Ho Chi Minh City. Researching the properties and applications of nano concrete in Vietnam with the desire to apply to some types of bridge and road structures today and step by step research on nano concrete application in designing some structure of bridges, roads, and other special works. With new materials used to determine the mechanical properties of materials and the characteristics of destruction at the limit of failure is essential. Moreover, high strength concrete materials are often brittle, so it is necessary to study measures to increase the plasticity to obtain the structure to ensure the requirements of the bearing and nano concrete with steel fibers. Steel fibers will make nano concrete increase tensile resistance in concrete.
\end{abstract}

\section{Introduction}

Concrete is the material used mainly in construction projects and is the object of research of many scientific works to improve quality and develop the construction industry to new height levels. The current technology development trend of concrete not only focuses on the intensity but also on the features, destructive characteristics and sustainability of the harsh environment [1-3].

Two recent developments in concrete technology are the use of additives and the addition of super-fine component materials such as fly ash, siliceous soot, and mineral powder with the aim of improving good structure at the micro-level, enhancing reactions to remove harmful components, reducing the amount of cement used to bring sustainability $[4,5]$.

Nano concrete are similar to normal concrete because of their very low tensile strength [6-9]. When adding steel fibers in nano concrete helps promote the advantages of steel fiber concrete and improve some properties in nano concrete [10-14]. The interaction between steel fibers and concrete has created the quality of steel fibers nano concrete. Understanding

*Corresponding author: lamthanhquangkhai@gmail.com 
this interaction will assess the quality of concrete, the role of steel fibers and predict the mechanical capabilities of steel fibers nano concrete [15].

\section{Materials and methods}

\subsection{Materials}

The design of the nano concrete mixture is a reasonable choice of component materials to obtain high quality and high-performance concrete mixtures. In principle, just like normal concrete, when designing nano concrete components, it is necessary to ensure the following requirements: strength requirements of concrete; requirements for construction conditions; requirements for fabrication materials; preliminary determination of the composition of concrete; calibration of concrete components through test results; monitoring and inspection of concrete pouring process and making necessary corrections in the production process due to changes in aggregate properties or other factors nano concrete samples.

Cement: Currently, cement is often classified according to ASTM standards with 5 types as follows and is presented in Table 1.

Cement types 1 and 2 are ordinary cement; type 3 has high heat of hydration; type 4-5 cement is used for special structures (low heat cement).

Table 1. Cement types are classified according to ASTM standards.

\begin{tabular}{|c|c|c|c|c|}
\hline Group ASTM & $\mathrm{C}_{3} \mathrm{~S}(\%)$ & $\mathrm{C}_{2} \mathrm{~S}(\%)$ & $\mathrm{C}_{3} \mathrm{~A}(\%)$ & $\mathrm{C}_{4} \mathrm{AF}(\%)$ \\
\hline $\mathrm{G} 1$ & 55 & 16 & 11 & 7 \\
\hline $\mathrm{G} 2$ & 44 & 26 & 5 & 15 \\
\hline $\mathrm{G} 3$ & 63 & 10 & 10 & 8 \\
\hline G4 & 25 & 47 & 4 & 15 \\
\hline G5 & 40 & 40 & 4 & 9 \\
\hline
\end{tabular}

Table 2. Chemical composition of cement types in Vietnam.

\begin{tabular}{|c|c|c|c|c|}
\hline Type & $\mathrm{C}_{3} \mathrm{~S}(\%)$ & $\mathrm{C}_{2} \mathrm{~S}(\%)$ & $\mathrm{C}_{3} \mathrm{~A}(\%)$ & $\mathrm{C}_{4} \mathrm{AF}(\%)$ \\
\hline Nghi Son & 52 & 29 & 6 & 10 \\
\hline But Son & 51 & 24 & 8.5 & 11 \\
\hline Hoang thach & 56 & 18 & 10 & 10 \\
\hline Bim Son & 67 & 8 & 5 & 15 \\
\hline
\end{tabular}

PC40- But Son Cement is used in research with the following characteristics (Figure 1) $[16,17]$.

- Specific mass $3.13 \mathrm{~g} / \mathrm{cm}^{3}$;

- Standard water volume $28 \%$;

- Volume stability $2.2 \mathrm{~mm}$;

- Smoothness (sieve $0.08 \mathrm{~mm}$ ) is $3.7 \%$;

- The time started to agglomerated the 120 minutes, ending the agglomerated of 216 minutes;

- Tensile strength when bending 3 days $5.87 \mathrm{MPa}$ and compressive strength 22.2MPa;

- Tensile strength when bending 7 days $6.5 \mathrm{MPa}$ and compressive strength $30 \mathrm{MPa}$;

- Tensile strength when bending 28 days $7 \mathrm{MPa}$ and compressive strength $43 \mathrm{MPa}$. 


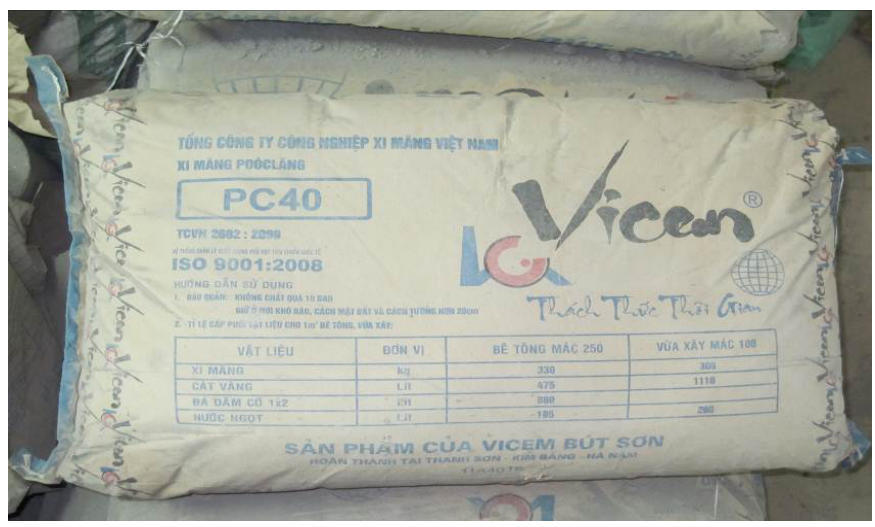

Fig. 1. PC40 But Son Cement.

Large aggregate (stone): The stone used for concrete experiments is macadam. Stone has a cubic shape, not much impurities and has few flat particles. Flat rhombic stones and weak soft particles, weathered particles affect concrete strength. The content of Cl- ion in aggregate must not exceed $0.01 \%$ of alkali-silica reaction ability for large aggregates as specified with small aggregates. Quarries are used in research in province Hoa Binh and are shown in Figure 2

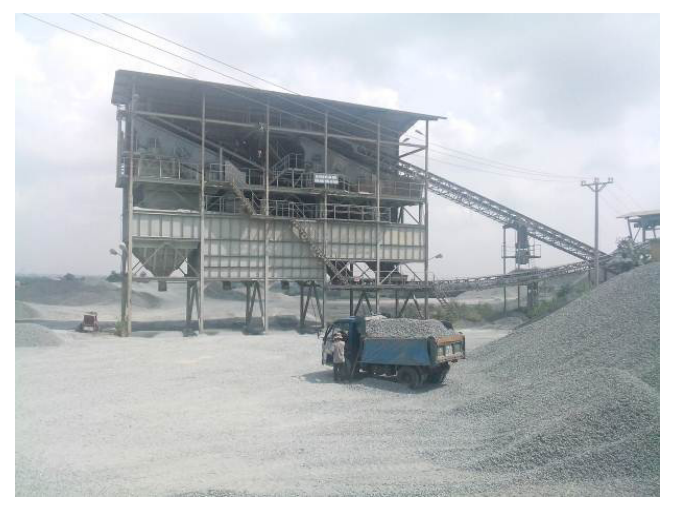

Fig. 2. Quarry Sunway (Hoa Binh province).

The compressive strength of the Quarry Sunway obtained from the experiment is presented in Tables 3-5.

Table 3. Experimental results of compressive strength of stones (Sunway quarries).

\begin{tabular}{|c|c|c|c|c|c|c|c|}
\hline \multicolumn{4}{|c|}{ Stone strength in dry status } & \multicolumn{4}{|c|}{ Stone strength in saturation status } \\
\hline $\begin{array}{c}\text { Sample } \\
\text { area } \mathrm{mm}^{2}\end{array}$ & $\begin{array}{c}\text { Des } \\
\text { Troy } \\
\text { ing force, } \mathrm{kN}\end{array}$ & $\begin{array}{c}\text { Inten } \\
\text { sity } \\
\mathrm{MPa}\end{array}$ & $\begin{array}{c}\text { Medi } \\
\text { um inten } \\
\text { sity } \\
\mathrm{MPa}\end{array}$ & $\begin{array}{c}\text { Sample } \\
\text { area, } \mathrm{mm}^{2}\end{array}$ & $\begin{array}{l}\text { Des } \\
\text { Troy } \\
\text { ing } \\
\text { force, } \\
\mathrm{kN}\end{array}$ & $\begin{array}{c}\text { Inten } \\
\text { sity } \\
\mathrm{MPa}\end{array}$ & $\begin{array}{c}\text { Medi } \\
\text { um inten } \\
\text { sity } \\
\mathrm{MPa}\end{array}$ \\
\hline 1384.7 & 184 & 132.9 & \multirow{2}{*}{135.6} & 1451.4 & 178 & 122.6 & \multirow{2}{*}{126.5} \\
\hline 1451.4 & 203 & 139.9 & & 1384.7 & 182 & 131.4 & \\
\hline
\end{tabular}




\begin{tabular}{|c|c|c|c|c|c|c|}
\hline 1451.4 & 194 & 133.7 & 1384.7 & 181 & 130.7 & \\
\hline 1519.7 & 198 & 130.3 & 1384.7 & 180 & 130.0 & \\
\hline 1384.7 & 196 & 141.5 & 1519.7 & 179 & 117.8 & \\
\hline \multicolumn{2}{|c|}{$\begin{array}{l}\text { Highest sample strength, } \\
\qquad \mathrm{MPa}\end{array}$} & 141.5 & \multicolumn{2}{|c|}{$\begin{array}{l}\text { Highest sample } \\
\text { strength, } \mathrm{MPa}\end{array}$} & \multicolumn{2}{|c|}{131.4} \\
\hline \multicolumn{2}{|c|}{$\begin{array}{c}\text { Lowest sample strength, } \\
\mathrm{MPa}\end{array}$} & 130.3 & \multicolumn{2}{|c|}{$\begin{array}{l}\text { Lowest sample } \\
\text { strength, MPa }\end{array}$} & \multicolumn{2}{|c|}{117.8} \\
\hline
\end{tabular}

Table 4. Experimental results of physical and mechanical properties of stone.

\begin{tabular}{|c|c|c|c|c|}
\hline Stone & $\begin{array}{c}\text { Specific } \\
\text { mass, } \\
\mathrm{g} / \mathrm{cm}^{3}\end{array}$ & $\begin{array}{c}\text { Mass of } \\
\text { compacted } \\
\text { volume, } \\
\mathrm{g} / \mathrm{cm}^{3}\end{array}$ & $\begin{array}{c}\text { Water } \\
\text { absorption, \% }\end{array}$ & $\begin{array}{c}\text { Humidity, } \\
\%\end{array}$ \\
\hline $\begin{array}{c}\mathrm{D}_{\max }= \\
12.5 \\
\mathrm{~mm}\end{array}$ & 2.74 & 1.615 & 0.71 & 0.4 \\
\hline
\end{tabular}

Table 5. Experimental results of particle composition of stones $D_{\max }=12.5 \mathrm{~mm}$.

\begin{tabular}{|c|c|c|c|c|}
\hline $\begin{array}{c}\text { Sieve } \\
\text { size, } \\
\mathrm{mm}\end{array}$ & $\begin{array}{c}\text { Particle on } \\
\text { sieves, } \mathrm{g}\end{array}$ & $\begin{array}{c}\text { On the } \\
\text { sieve, } \mathrm{g}\end{array}$ & $\begin{array}{c}\text { \% On the } \\
\text { sieve }\end{array}$ & $\begin{array}{c}\% \text { Standard } \\
\text { residual } \\
\text { volume }\end{array}$ \\
\hline 19 & 0 & 0 & 0.0 & 0 \\
\hline 12.5 & 1250 & 1250 & 6.0 & $0-10$ \\
\hline 9.5 & 8460 & 9710 & 46.5 & $30-60$ \\
\hline 4.75 & 10130 & 19840 & 95.0 & $85-100$ \\
\hline 2.36 & 1050 & 20890 & 100.0 & $95-100$ \\
\hline Bottom & 0 & 20890 & 100.0 & \\
\hline
\end{tabular}

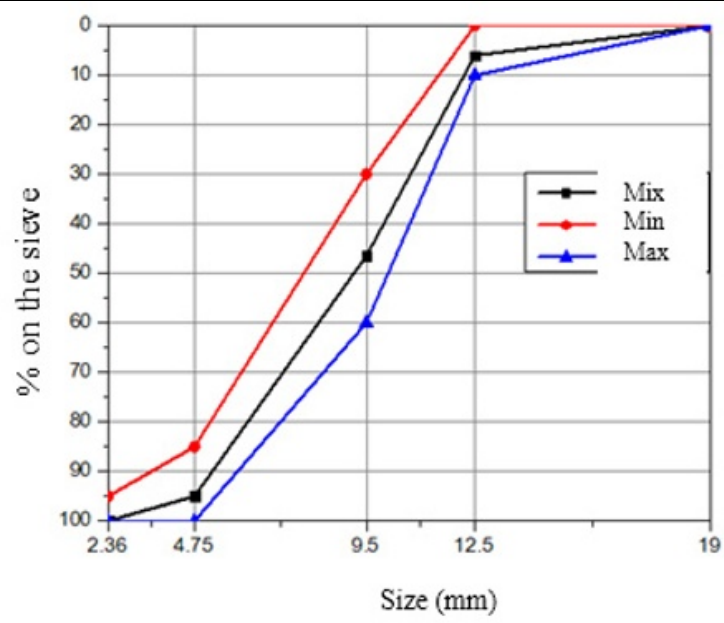

Fig. 3. Curve diagram of stone. 
Small aggregate (sand): Small aggregate used to manufacture experimental concrete is raw sand, exploited on Hong River (Viet Tri mine). The sand is analyzed for grain composition according to ASTM C33. The grain composition results are presented in Table 7. The grain composition of sand is ensured according to ASTM C33 [18].

Table 6. Experimental results of mechanical properties of sand.

\begin{tabular}{|c|c|c|c|c|}
\hline $\begin{array}{c}\text { Specific } \\
\text { mass, } \\
\mathrm{g} / \mathrm{cm}^{3}\end{array}$ & $\begin{array}{c}\text { Mass of } \\
\text { compacted } \\
\text { volume, } \\
\mathrm{g} / \mathrm{cm}^{3}\end{array}$ & $\begin{array}{c}\text { Scale } \\
\text { module }\end{array}$ & $\begin{array}{c}\text { Water } \\
\text { absorption, } \\
\%\end{array}$ & $\begin{array}{c}\text { Humidity, } \\
\%\end{array}$ \\
\hline 2.66 & 1.74 & 2.73 & 1.05 & 2 \\
\hline
\end{tabular}

Table 7. Experimental results of grain composition of sand.

\begin{tabular}{|c|c|c|c|}
\hline Sieve size, $\mathrm{mm}$ & $\begin{array}{c}\text { \% on the } \\
\text { sieve }\end{array}$ & $\begin{array}{c}\text { \% through } \\
\text { the sieve }\end{array}$ & $\begin{array}{c}\text { \% standard } \\
\text { residual volume }\end{array}$ \\
\hline 4.75 & 0.0 & 100 & $95-100$ \\
\hline 2.36 & 19.2 & 80.8 & $80-100$ \\
\hline 1.18 & 15.9 & 64.8 & $50-85$ \\
\hline 0.6 & 13.6 & 51.2 & $25-60$ \\
\hline 0.3 & 25.3 & 25.9 & $5-30$ \\
\hline 0.15 & 21.6 & 4.3 & $0-10$ \\
\hline Bottom & 4.3 & 0.0 & \\
\hline
\end{tabular}

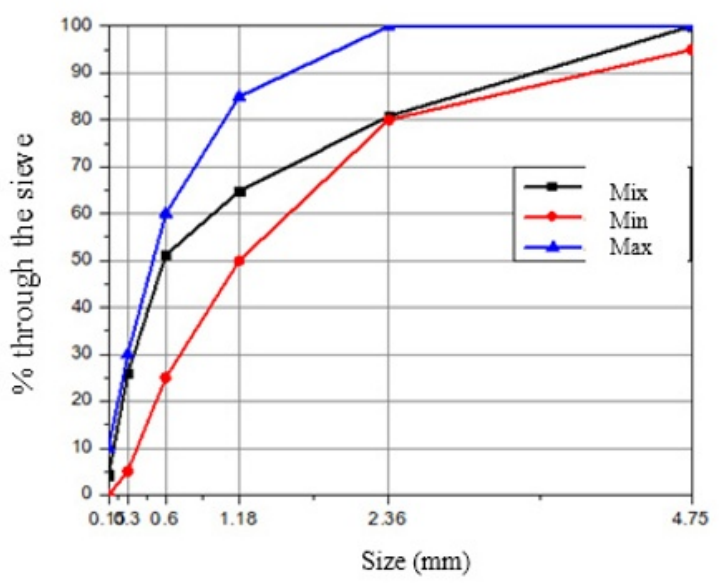

Fig. 4. Chart of sand grain composition.

Water: Water for concrete construction (aggregate washing, concrete mixing and maintenance) is taken from the tap water of the domestic water supply system. Quality assurance of impurities that affect the properties of concrete and no side effects with additives.

Silica: Silica is a byproduct derived from the quartz burning process with coal in electric arc furnaces of silicon and silicon steel alloys, the smoke emitted with high amorphous silicon dioxide content and contains very fine spherical crystals.

Silica is composed of very fine glass particles with a surface area of $20.000 \mathrm{~m}^{2} / \mathrm{kg}$ when measured by Nitrogen absorption. The particle size distribution of a typical silicon soot 
shows that most particles are less than $0.1 \mu \mathrm{m}$ smaller than the size of cement particles 100 times.

Study using Sika silicafume Sikacrete PP1 original product, in accordance with ASTM standards C1240-03. Specific mass $2.2\left(\mathrm{~g} / \mathrm{cm}^{3}\right)$.

Table 8. Information on silicon Sikacrete PP1.

\begin{tabular}{|c|c|}
\hline $\begin{array}{l}\text { Product } \\
\text { Description }\end{array}$ & $\begin{array}{c}\text { Sikacrete PP1 is a new generation concrete } \\
\text { powder additive, based on Sika's Silica fume } \\
\text { technology, in accordance with ASTM C } \\
1240 .\end{array}$ \\
\hline Applications & $\begin{array}{c}\text { Sikacrete PP1 is used in structural concrete, } \\
\text { precast concrete and in areas requiring high } \\
\text { quality of fresh concrete and hardened } \\
\text { concrete. }\end{array}$ \\
\hline Advantages & $\begin{array}{c}\text { When used together with superplasticizer, } \\
\text { concrete will achieve the following properties } \\
\text { + High construction performance } \\
\text { + Increased durability } \\
\text { + Achieve early strength } \\
\text { + Increase the final intensity } \\
\text { + Increased abrasion resistance } \\
\text { + Increased sulfate resistance } \\
\text { + Increased resistance to significant air } \\
\text { penetration } \\
\text { + Minimize the diffusion of chloride }\end{array}$ \\
\hline Form /Color & Powder / Gray \\
\hline Pack & $20 \mathrm{~kg}$ bag \\
\hline $\begin{array}{l}\text { Storage } \\
\text { conditions }\end{array}$ & Cool dry place \\
\hline Expiry date & $\begin{array}{c}\text { Minimum } 24 \text { months if properly stored in } \\
\text { unopened original packaging }\end{array}$ \\
\hline Origin & $\begin{array}{l}\text { Silica fume pozzolanic with tightly controlled } \\
\text { size accuracy. }\end{array}$ \\
\hline Specific mass & $2.2 \mathrm{~g} / \mathrm{cm}^{3}$ \\
\hline Amount & $5-10 \%$ by weight of cement \\
\hline
\end{tabular}

Nano silic: Nano materials can be broadly defined as materials that, in the structure of the components, should be at least one nanometer in size. $\left(10^{-9} \mathrm{~m}\right)$.

Nanoscale materials, including nanoparticles, fibers and nanotubes, nanoparticles are prepared in different ways. At the nanoscale, the material will have special features that traditional materials do not have, which is due to the size reduction and the increase in the surface area of this material.

Some researches in the world have used nanomaterials including: nano $\mathrm{SiO}_{2}$, nano $\mathrm{Al}_{2} \mathrm{O}_{3}$, nano $\mathrm{TiO}$, nano $\mathrm{CaCO}_{3}$ to improve some characteristics of cement, to increase the hydration reactions of cement, making Tighter bonding in cement mortar structure. The participation of nano optimizes the C-S-H gel structure to make concrete more durable.

The study used silicon Fusil 200 nano product of Chinese Fuchang chemical company with the following specifications are presented in Table 9. 
Table 9. Silicon nano information Fusil 200.

\begin{tabular}{|c|c|}
\hline Product Description & $\begin{array}{c}\text { Is a material made with nano } \\
\text { technology. Particle size ranges } \\
\text { from 5-40 nm. }\end{array}$ \\
\hline Pack & $10 \mathrm{~kg} \mathrm{bag}$ \\
\hline Storage conditions & Cool dry place \\
\hline Expiry date & $\begin{array}{c}\text { For 2 years from the date of } \\
\text { manufacture }\end{array}$ \\
\hline Surface area & $200 \pm 15 \mathrm{~m}^{2} / \mathrm{g}$ \\
\hline pH & $3.6-4.3$ \\
\hline $\begin{array}{c}\text { Loss at a temperature of } \\
1000^{\circ} \mathrm{C} \text { for } 2 \text { hours }\end{array}$ & $\leq 1 \%$ \\
\hline Amount on sieve & $\leq 0.05 \%$ \\
\hline Content $\mathrm{SiO}{ }_{2}$ & $\geq 99.8 \%$ \\
\hline Mass of volume & $30-60 \mathrm{~g} / 1$ \\
\hline Structure & Amorphous \\
\hline
\end{tabular}

Silicon nano with a size of 5-40 $\mathrm{nm}$. The results of XRD and SEM analysis to evaluate the size and shape of silicon nano are shown in Figure 5 and Figure 6. From XRD analysis, the difference from $16^{\circ}$ to $30^{\circ}$ shows the compounds in the form nano and amorphous state. From the SEM test image of nano silicon, it can be seen that the nanoparticle has a spherical shape with a size of $13 \mathrm{~nm}$.

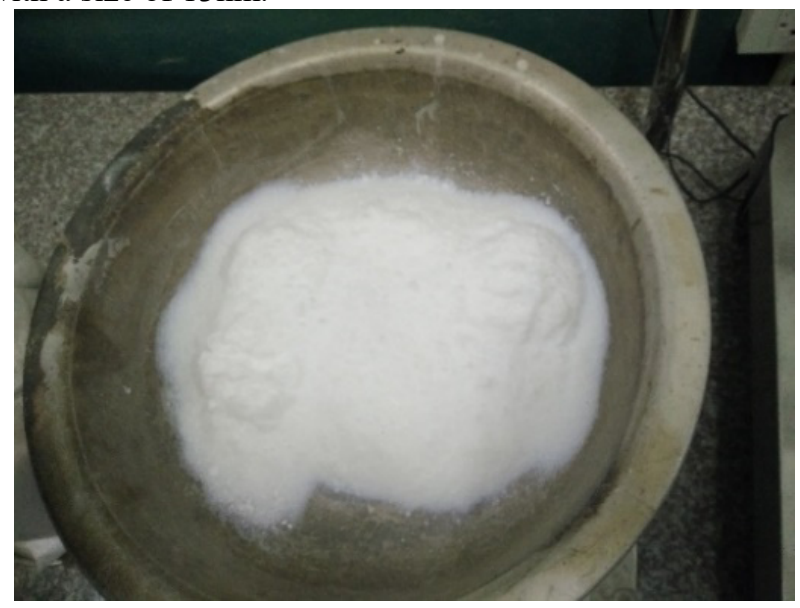

Fig. 5. Nano silica (Fusil 200). 


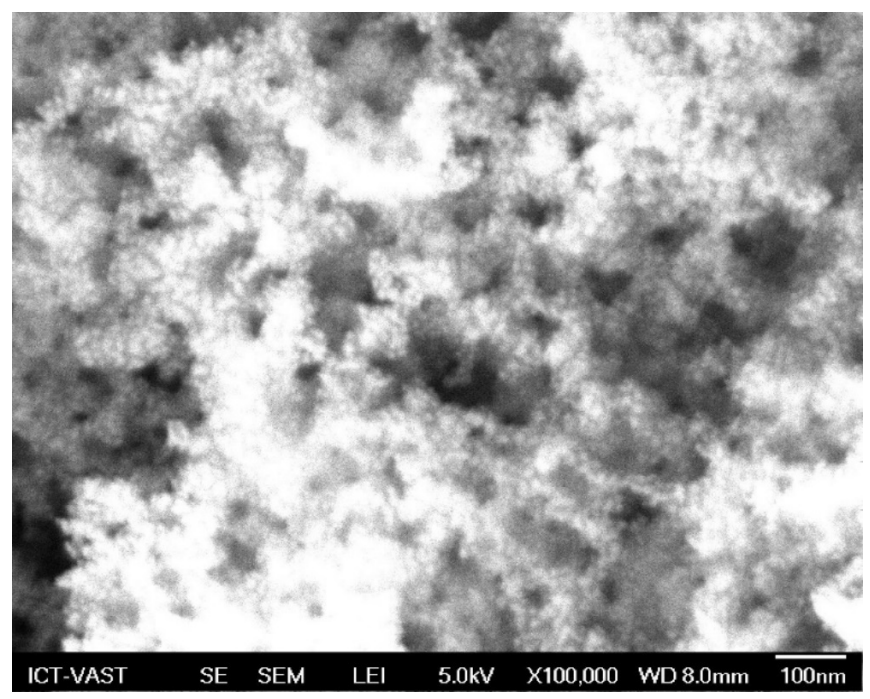

Fig. 6. SEM scans of silica nano.

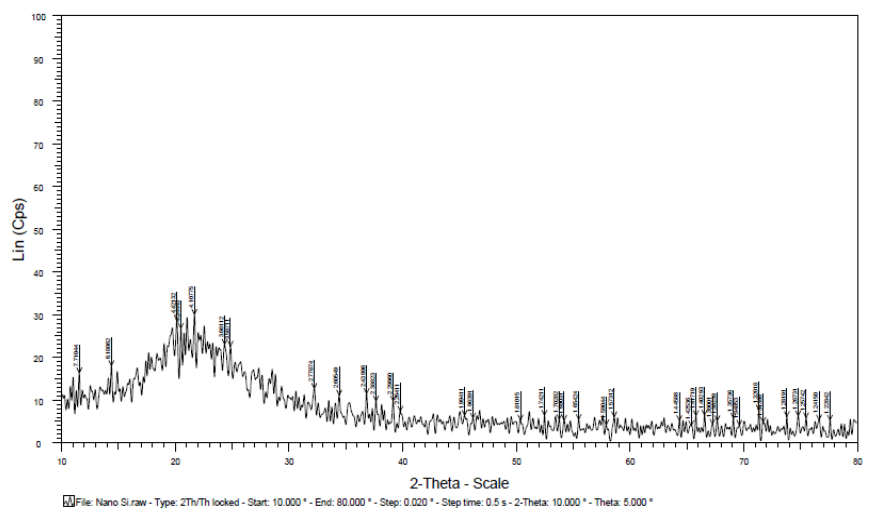

Fig. 7. Results of XRD scans of silica nano.

Chemical additives: Chemical additives are generally made from lignin sulphonate, carbonxilic acids (high molecular phenol) are hydrated, groups of carbohydrates, Melamine, Naptalin. The choice of type and dosage should be conducted by experiments. These chemical additives significantly increase compressive strength, control the setting rate, accelerate the strength, improve the workability and durability over time of concrete.

For nano concrete in this study, high quality concrete components are designed that require the use of superplastic additives to control the Water/Adhesives.

High water reducers according to ASTM C494 type F and G bring higher intensity and earlier. High water reducer is intended to increase the intensity if it stays the same or increases the slump from 3-4 times if it stays the same. In Vietnam these substances are called superplastic additives and they have been commonly used in large bridge projects with a dosage of 0.5-2.5 liters $/ 100 \mathrm{~kg}$ of cement.

Additives used in concrete are Sika's Sika Viscocrete 3000-20. A G-type superplasticizer, meeting ASTM C494 are presented in Table 10. 
Table 10. Information of additives Sika Viscocrete 3000-20.

\begin{tabular}{|c|c|}
\hline Product Description & $\begin{array}{c}\text { Sika Viscocret 3000-20 is a 3rd generation high-tech polymer-based } \\
\text { plasticizer with efficient flowability and easy concrete injection. } \\
\text { Sika Viscocret 3000-20 complies with ASTM C494 Type G }\end{array}$ \\
\hline Origin & Polycarboxylat improved in water \\
\hline Form / Color & Liquid / Light brown \\
\hline Pack & $5 / 25 / 2000$ liters \\
\hline Storage conditions & Store in dry conditions, avoid direct sunlight and temperatures from \\
$+5^{\circ} \mathrm{C}$ and $30^{\circ} \mathrm{C}$
\end{tabular}

\section{Results}

\subsection{Determining the composition of nano concrete}

Steps to design nano concrete components are carried out according to ACI 211.4R-08 [19], standard design of high strength concrete components. The superplasticizer additive content is determined according to the manufacturer's instructions and practically adjusted to ensure the required slump of the concrete mixture.

Silica and nano silicon silice content is added to the aggregate according to the manufacturer's recommended ratios and reference materials. Silica and nano-silica components are considered binder components, so the amount of cement used will be corrected to an appropriate proportion in the gradation calculation process.

The aggregates serving the experiment are calculated and designed according to the absolute volume method based on the optimal theory of density. Assuming a total solid volume of $1 \mathrm{~m}^{3}$. Each component material occupies a certain proportion by mass or by volume, with hypothesis $\sum_{i=1}^{n} V_{i}=1$.

Step 1: Select slump and strength of concrete;

Step 2: Choose $\mathrm{D}_{\max }$ size of large aggregate;

Step 3: Choose the min aggregate content;

Step 4: Determine the amount of water and air content;

Step 5: select the ratio $\mathrm{w} / \mathrm{c}+\mathrm{p}$ (Water/adhesives ratio);

Step 6: Calculate the adhesives content;

Step 7: Determine the ratio of the base mixture to the cement adhesive;

Step 8: Determine the mixed ingredient for $1 \mathrm{~m}^{3}$ of concrete.

\subsection{Identify and synthesize component materials for nano concrete mixtures}

Based on the research objectives, the authors have designed a number of gradients with a percentage change in silicon nano. The change for the purpose of selecting the composition of nano concrete has the most optimal results in terms of intensity. The selected mix will continue to be used in subsequent experiments of the study. 
Table 11. High strength concrete mixtures.

\begin{tabular}{|c|c|c|c|}
\hline Mixtures & Nano silic (\%) & Silica (\%) & Symbol \\
\hline Mixture 1 & 0 & 5 & HPC \\
\hline Mixture 2 & 0.5 & 5 & HPCN0.5 \\
\hline Mixture 3 & 1.5 & 5 & HPCN1.5 \\
\hline Mixture 4 & 3 & 5 & HPCN3.0 \\
\hline
\end{tabular}

The aggregates are calculated based on the design of high strength concrete components according to ACI 211, 4R-08 [19]. The aggregates are synthesized as a basis for calculating batches to conduct casting samples.

Table 12. Aggregate concrete design with compressive strength of $80 \mathrm{Mpa}$.

\begin{tabular}{|c|c|c|c|c|}
\hline Ingredient & HPC & HPCN0.5 & HPCN1.5 & HPCN3.0 \\
\hline Cement, $\mathrm{kg}$ & 594 & 594 & 594 & 594 \\
\hline Stone, $\mathrm{kg}$ & 1098 & 1098 & 1098 & 1098 \\
\hline Sand, $\mathrm{kg}$ & 548 & 604 & 592 & 574 \\
\hline Water, $\mathrm{kg}$ & 151.8 & 144.7 & 146.1 & 148.5 \\
\hline PG viscocrete, liters & 6.53 & 6.53 & 6.53 & 6.53 \\
\hline Nano silic, $\mathrm{kg}$ & 0 & 3.15 & 9.53 & 19.37 \\
\hline Silica, $\mathrm{kg}$ & 29.7 & 29.7 & 29.7 & 29.7 \\
\hline
\end{tabular}

\subsection{Increasing the tensile resistance of nano concrete using steel fibers [20, 21]}

Based on the aggregates designed in section 2, conduct casting and check the tensile strength when bending.

The interaction between steel fibers and concrete creates the quality of steel fiber concrete. Understanding this interaction will assess the quality of the base concrete material, the role of steel fibers and predict the mechanical capabilities of steel fiber concrete.

According to Hsu, Slate, Sturman \& Winter in the article "Microcracking of Plain Concrete and the Shape of the Slress-Strain Curve" have shown that there are microscopic cracks at the surface of large-sized coarse aggregate elements. These cracks exist in no-load state.

When concrete is pulled under different loads, including fatigue, micro-cracks will spread along the surface of the aggregate and part of the concrete block around the aggregate. Because concrete blocks contain smaller cement and aggregates, in which steel fibers are randomly mixed and aligned, although they can be altered by the relative position of the raw aggregate.

Concrete blocks become steel fiber concrete mixtures. Tensile strength of steel fibers can cause initial cracking in the mixture but the level of steel fibers depends on the amount and effectiveness of the steel fibers in the area where cracks may occur. The processes involved in the interaction between fibers and concrete base mainly occur in relatively small areas around fibers and substrate materials.

The base concrete material is brittle so the stress transmission effect will be studied for both cases: before cracking and after cracking, so the processes are also completely different corresponding to the two cases.

Before any cracks occur, the transmission of elastic stress is an important first mechanism, the vertical displacement between steel fibers and the substrate material at the interface is clearly shown. The elastic slip stress transfer is the main mechanism, used to predict the value: stress at the first crack.

Table 13. Number and size of samples used for testing. 


\begin{tabular}{|c|c|c|c|c|}
\hline $\begin{array}{c}\text { Experimental } \\
\text { content }\end{array}$ & Mixture & $\begin{array}{c}\text { Number of } \\
\text { samples }\end{array}$ & Sample shapes & Size, cm \\
\hline $\begin{array}{c}\text { Tensile strength } \\
\text { when bending }\end{array}$ & $\begin{array}{c}\text { HPCN1.5+ steel } \\
\text { fibers } 78.5 \mathrm{~kg} / \mathrm{m}^{3}\end{array}$ & 3 & $\begin{array}{c}\text { Beam } \\
\text { samlpe }\end{array}$ & $10 \times 10 \times 40$ \\
\hline
\end{tabular}

Table 14. Experimental results of tensile strength when bending.

\begin{tabular}{|c|c|c|c|}
\hline Samples & Force, $\mathrm{kN}$ & $\begin{array}{c}\text { Tensile strength when } \\
\text { bending, MPa }\end{array}$ & \multirow{2}{*}{ Medium, MPa } \\
\hline M1 & 55.2 & 16.56 & \multirow{2}{*}{16.93} \\
\hline M2 & 58.9 & 17.67 & \\
\hline M3 & 55.2 & 16.56 & \\
\hline
\end{tabular}

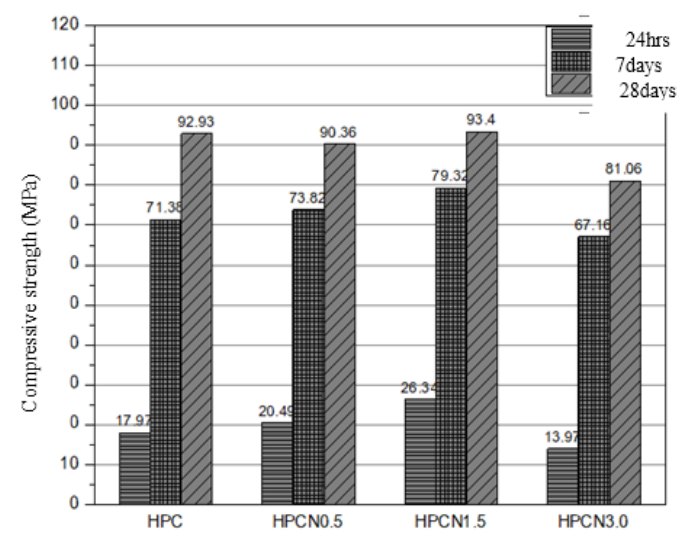

Fig. 8. Compressive strength of nano concrete.

Figure 8 shows that the highest compressive strength of HPCN1.5 concrete samples at 24 hours, 7 days, 28 days with the highest results. If compared with concrete using only siliceous soot (HPC), the compressive strength of HPCN1.5 grows faster in 24 hours and 7 days with the results increasing respectively $46.58 \%$ and $11.12 \%$.

\section{Conclusion}

Based on the results of the study lead to the following conclusions:

1. The study has determined that concrete is mixed with additional nano-silicon components with a characteristic intensity of $80 \mathrm{MPa}$ according to ACI $211 \mathrm{R} 4-08$ standard.

2. The ratio of $1.5 \%$ nano silicon will effectively form early strength at 24 hours and 7 days due to the improvement of microstructures and promote Pozzolanic reactions.

3 . When using 3\% nano silicon, the concrete mixture has a lumping phenomenon that leads to the workability of the mixture and the compressive strength of the sample is reduced. 
4. When adding steel fibers to nano concrete, it increases tensile strength when bending in beams.

\section{References}

1. Wei Li, Linkai Xiao, Xiaochu Wang and Yi Ran, A Review of Mechanical Properties and Durability of Nano-concrete. Ad. in Eng. Res., vol. 136 (2017)

2. P.S. Surendra, Advances in Using Nano Materials in Construction. Hong Kong Concrete Institute, Hong Kong (2017)

3. M. Jafarbeglou, A.A. Ramezanianpour, Nanoscience and Nano Engineering in Concrete Advances, A Review. Int. J. of Nanoscie. and Nanotech., vol. 11, Issue 4, 263-273 (2015)

4. B. Szostak, G.L. Golewski, Effect of Nano Admixture of CSH on Selected Strength Parameters of Concrete Including Fly Ash. IOP Conf. Series: Mat. Scie. and Eng., 416 (2018)

5. M.-H. Zhang, J. Islam, Use of nano-silica to reduce setting time and increase early strength of concretes with high volumes of fly ash or slag. Const. and Build. Mat. (2012)

6. K. Sobolev, I. Flores, L.M. Torres-Martinez, P.L. Valdez, E. Zarazua, E.L. Cuellar, Eng. of SiO2 Nanopart. for Opt. Perf.e in Nano Cement-Bas. Mat., Nanotech. in Const. 3, 139-148 (2009)

7. R. Sakthivel, N. Balasundaram, Experimental investigation on behaviour of nano concrete. Int. J. of Civil Eng. and Tech., 7, Issue 2, 315-320 (2016)

8. Yi Zhi Yan, Zhi Min Su, Liang Wu, Research on Mechanical Properties of NanoConcrete. Ad. Mat. Res., 628, 50-54, (2013)

9. Thi My Dung Do, Thanh Quang Khai Lam, Solutions to improve the quality of mass concrete construction in climate conditions of Southern Vietnam. Int. J. of Inn. Tech. and Exp. Eng., 8, Issue 6C2, 4/2019,188-192 (2019)

10. C.Y. Li, T.W. Chou, Modeling of damage sensing in fiber composites using carbon nano-tube networks. Comp. Scie. and Tech. 68, 3373-3379 (2008)

11. Lam Thanh Quang Khai, Do Thi My Dung, "Stress-strain in multi-layer reinforced concrete doubly curved shell roof". Int. J. of Inn. Tech. and Exp. Eng., 8, Issue 4S2, 3/2019, 419-424 (2019)

12. Thanh Quang Khai Lam, Thi My Dung Do, Sliding between layers in 2-layer reinforced concrete beams and shell. Int. J. of Eng. and Ad. Tech., 8, Issue 5, 6/2019, 1867-1871, (2019)

13. Nguyen Ngoc Long, Study the selection and design of steel fiber concrete components suitable for the use of bridge structures in Vietnam. Ministry-lev. scie. Res. Top., (2005)

14. Thanh Quang Khai Lam, Thi My Dung Do, Effect of each shell thickness on deformation stress and the ability for causing the cracks in the multilayer doubly curved shell roof. Int. J. of Inn. Tech. and Exp. Eng., 8, Issue 6C2, 4/2019, 215-220 (2019)

15. Thi My Dung Do, Thanh Quang Khai Lam, Analysis of Risk Problems in Construction by $R$ software. Int. J. of Eng. and Ad. Tech., 8 (5), 6/2019, 1872-1875 (2019)

16. CP 52-104-09. Reinforced concrete structure. Moscow (2009) 
17. TCVN 5574-2012, "Concrete and reinforced concrete, structures-Design standard", Vietnamese standard (2012)

18. ASTM C33, "Standard Specification for Concrete Aggregates" (2002)

19. ACI 211.4R, "Guide for Selecting Proportions for High-Strength Concrete Using Portland Cement and Other Cementitious Materials" (2008)

20. ACI 544.1R-96, "State-of-the-Art Report on Fiber Reinforced Concrete"

21. ASTM A820-01, "Standard Specification for Steel Fibers for Fiber-Reinforced Concrete" 